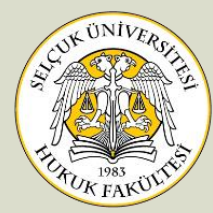

\title{
SÖZLEŞME ÖNCESİ GÖRÜŞMELERİN KESİLMESİ BAĞLAMINDA CULPA IN CONTRAHENDO SORUMLULUĞU VE OLUMSUZ ZARAR
}

\author{
Arş. Gör. Dr. Özkan ÖZYAKIŞIR* Arş. Gör. Muhammed K. GANBARİ*
}

\section{Öz}

Hukuki güvenlik, sosyal ve ticari hayatın en temel ihtiyaçlarından biridir. Sosyal ve ticari hayat, çoğu zaman kişilerin, muhataplarına güvenerek iş(lem) yapmalarını gerekli kılmaktadır. Aralarındaki güven ilişkisine dayanarak hareket eden kişi, güveni boşa çıkarıldığında uğradığı zararların tazminini bekler. Bu durum, hukuki güvenlik ilkesinin bir tezahürüdür. Tüm bunlar, güven ilişkisine hukuki bir statü kazandırılması gerekliliğini ortaya çıkarmıştır.

Güven ilişkisinin hukuken korunması, dürüstlük kuralının bir gereğidir. Buna göre, aralarında güven ilişkisi bulunan taraflar, birbirlerine karşı gerekli özeni gösterme; şahıs ve malvarlığı değerlerine zarar vermeme yükümlülüğü altındadır. Sözleşme görüşmeleri kapsamında oluşan güven de bu noktada culpa in contrahendo sorumluluğunu doğurmaktadır. Bu sorumluluk hâlinde, kural olarak olumsuz zararın tazmini gerekmektedir.

* $\quad$ Arş. Gör., Ankara Hacı Bayram Veli Üniversitesi, Hukuk Fakültesi, Medeni Hukuk Anabilim Dalı, Ankara, Türkiye | Asst., Ankara Hacı Bayram Veli University, Faculty of Law, Department of Civil Law, Ankara, Turkey.

囚 o_ozyakisir36@hotmail.com • ORCID 0000-0002-1401-9891

* Arş. Gör., Tokat Gaziosmanpaşa Üniversitesi, Hukuk Fakültesi, Medeni Hukuk Anabilim Dalı, Tokat, Türkiye | Asst., Tokat Gaziosmanpaşa University, Faculty of Law, Department of Civil Law, Tokat, Turkey.

凹 muhammed.ganbari@hbv.edu.tr • ORCID 0000-0001-7984-0333

Atıf Şekli | Cite As: ÖZYAKIŞIR Özkan, GANBARI Muhammed K. “Sözleşme Öncesi Görüşmelerin Kesilmesi Bağlamında Culpa In Contrahendo Sorumluluğu ve Olumsuz Zarar", SÜHFD., C. 28, S. 2, 2020, s. 745-775.

İntihal | Plagiarism: Bu makale intihal programında taranmış ve en az iki hakem incelemesinden geçmiştir. I This article has been scanned via a plagiarism software and reviewed by at least two referees. 


\title{
Anahtar Kelimeler
}

Güven İlişkisi • Dürüstlük Kuralı • Culpa in Contrahendo • Zarar • Olumsuz Zarar

\section{CULPA IN CONTRAHENDO LIABILITY AND RELIANCE DAMAGE IN THE CONTEXT OF TERMINATION OF CONTRACT NEGOTIATIONS}

\begin{abstract}
Legal certainty is a basic need for social and commercial life. Social and commercial life often requires people to do business and transaction by trusting their interlocutors. The person, acting based on the trust relationship claims the legal compensation of the damages arising from his trust. This is a manifestation of the legal certainty principle. All these result in the necessity to give a legal status to the trust relationship.

The legal protection of the trust relationship is a requirement of the rule of good faith. Accordingly, the parties with a trust relationship between them are under the obligation to take the necessary care towards each other and not to damage material and immaterial rights. At this point, trust relationship in contract negotiations brings the liability of culpa in contrahendo. In such liability, as a rule, compensation for the reliance damage is required.
\end{abstract}

\section{Key Words}

Trust Relationship • The Rule of Good Faith • Culpa in Contrahendo • Damage

- Reliance Damage

\section{GİRIŞ}

Sorumluluk hukukunda uzun zamandır yaşanan değişimin en temel özelliği, sorumluluk sebeplerinin genişlemesidir. Bu noktada sözleşme kaynaklı sorumluluğun sınırları da olabildiğine genişlemektedir. Sözleşme görüşmelerine başlayan kimseler, bu sürecin olumlu neticeleneceği inancıyla bir güven ilişkisi kurmaktadırlar. Bu güven ilişkisinin ne zaman bir hukuki sorumluluğa sebebiyet vereceği, sorumluluğun dayanağının ve kapsamının tespiti; hukuk güvenliliği ve uygulaması açısından elzem meselelerdir. Çalışma, bu konuların irdelenmesi amacını taşımaktadir.

Çalışma sırasında hukuk doktrininin ve pozitif hukukumuzdaki kanun koyucunun tercih ettiği terminolojiye sadık kalınmıştır. Özel bir anlam ifade edecek surette terminoloji kullanılmamıştır. 
Çalışma boyunca ilk olarak sorumluluk hukukundaki gelişmelerden biri olan edim yükümlülüğü kavramının içeriğinin nasıl genişlediği ve edim yükümlülügünden bağımsız borç ilişkisi teorisinin neyi ifade ettiği anlatılacaktır. Akabinde, tarafların sözleşme görüşmeleri ile oluşturdukları ilişkinin niteliği ve buna bağlı olarak culpa in contrahendo sorumluluğundan hangi durumlarda bahsedilebileceği ortaya konulacaktır. Daha sonra ise, culpa in contrahendo sorumluluğunu gerektiren bir durumun varlığ 1 halinde, sorumlu kimsenin, hangi tür zararlardan sorumlu olduğu meselesi irdelenecektir. Bu noktada özellikle olumsuz zarar üzerinde durulacaktır. Bununla birlikte doktrinde culpa in contrahendo halinde olumlu zararın tazmininin gerektiği yönündeki görüşe yalnızca değinilecektir. Ayrıca olumlu zararın tazminini öngören özel kanunî düzenlemeler ayrıntılı olarak tek tek ele alınmayacak yalnızca çalışma açısından gerektiği kadarıyla vurgulanacaktır.

\section{BORÇ İLISSKİ́İ KAVRAMI, EDIMDEN BAĞIMSIZ KANUNI BORÇ İLIŞKİsi}

\section{A. Borç İlişkisi Kavramı: Edim Yükümlülüğü ve Koruma Yükümlülüğ̈̈ Ayrımı}

İktisadi ve sosyal ilişkilerin, zaman içerisinde olabildiğince genişlemesi ve farklılaşması, hukuk alanında bazı kavramların yeniden tartışılması ve ele alınması ihtiyacını doğurmuştur. Söz konusu bu gelişmeler, "borç ilişkisi" kavramı üzerinde de etkisini hissettirmiştir. Borç ilişkisi kavramı, anlam, unsurları ve çerçevesi bakımından zaman içerisinde önemli bir genişleme yaşamıştır. Bu genişleme, borç ilişkisinin içeriği hususunda yeni bir anlayışın hâkim olmasına vesile olmuştur ${ }^{1}$. Modern hukuk doktrininde, borç ilişkisi, yeniden tanımlanmış ve bu ilişkinin edim yükümlülüğünden ibaret olmadı̆̆ı; edim yükümlülüğünü de kapsayan fakat edim yükümlülüğünden daha geniş bir içeriğe sahip olduğu sonucuna varılmıştır. Böylece doktrinde, borç ilişkisinin içeriğinin, edim yükümlülükleri ve koruma yükümlülüklerinden oluştuğu genel bir kabul görmüştür².

$1 \quad$ KALKAN OĞUZTÜRK, Burcu, Güven Sorumluluğu, İstanbul 2008, s. 73-75.

2 MEDİCUS, Dieter Allgemeiner Teil des BGB, Heidelberg 1982, s. 27; EREN, Fikret, Borçlar Hukuku Genel Hükümler, 24. Baskı, Ankara 2019, N. 61; DEMİRCíOĞLU, Huriye Reyhan, Güven Esası Uyarınca Sözleşme Görüşmelerindeki Kusurlu 
Edim yükümlülüğü ve koruma yükümlülüğü, birbirinden bağımsız ve farklı iki kavramdır³. Edim yükümlülügüu, tamamen ifa menfaatinin gerçekleşmesine yönelik yükümlülüğü ifade eder ${ }^{4}$. Bu yükümlülügün ifası ile tarafların sözleşmeden bekledikleri değişiklikler meydana gelir. Edim yükümlülüğü, esas olarak sözleşme ile doğar ve sözleşmenin somut içeriğiyle alakalıdır. Bu durum, edim yükümlülüğünün doğması için, geçerli bir sözleşmenin hukuken kurulmuş olması zorunluluğunu beraberinde getirmektedir; çünkü kurulmamış ya da geçersiz hale gelmiş bir sözleşmeden herhangi bir edim yükümlülüğü doğmaz ${ }^{5}$.

Taraflarının, bir sözleşme ilişkisi içine girmek istediklerinde, bundan bekledikleri ilk menfaat, edim menfaatidir. Ne var ki, borç ilişkisi içine giren taraflar, aynı zamanda edim dışında ve ondan bağımsız olarak mal ve şahıs varlıklarına sahiptirler. Bu mal ve şahıs varlıkları, tarafların içinde bulundukları borç ilişkisi nedeniyle zarar görebilir. Gerçekten de sözleşme ilişkisi içine girmek isteyen tarafların edim yükümlülügüunden kaynaklanan ifa menfaati haricinde; şahıs ve malvarlıklarının zarar görmemesine ilişkin menfaatlerinin korunması gerekmektedir. Bu gereklilik, koruma yükümlülüğü kavramını doğurmuştur ${ }^{6}$. Bu itibarla koruma yükümlülüğü, tarafların edim menfaati dışında, karşılıklı, birbirlerinin kişi

Davranıştan Doğan Sorumluluk (Culpa In Contrahendo Sorumluluğu), Ankara 2009, s. 120, 124; OĞUZMAN, M. Kemal/ÖZ, M. Turgut, Borçlar Hukuku Genel Hükümler Cilt I, Yeni Türk Borçlar Kanunu'na Göre Güncellenip, Genişletilmiş 16. Bası, İstanbul 2018, N. 17 dp.14; KIRCA, Çiğdem, Bilgi Vermeden Dolayı Üçüncü Kişiye Karşı Sorumluluk, Ankara 2004, s. 154,155; KARABAĞ BULUT, Nil, Üçüncü Kişiyi Koruyucu Etkili Sözleşme, İstanbul 2009, s. 59, 60; Michael Ernst - Kölbl, Schuldrecht Allgemeiner Teil, 1. Auflage, Niederle Media, 2008, s. 11, 12.

3 POHLMANN, Andre, Die Haftung wegen Verletzung von Aufklärungspflicht, Schriften zum Bürgerlichen Recht, Band 268, Dunker und Humbolt/ Berlin 2002, s. 22; BROX, Hans ve WALKER, Wolf-Dietrich, Allgemeines Schulrecht, Grundrisse des Recht, 34. Auflage, München 2010, s. 10; ERGÜNE, Mehmet Serkan, Olumsuz Zarar, İstanbul 2008, s. 112.

4 POHLMANN, s. 22, 23; EREN, N. 82; KIRCA, s. 156; KARABAĞ BULUT, s. 60.

5 BAYGIN, Cem, "Culpa in Contrahendo Sorumluluğu ve Amerikan Hukukundaki Uygulaması”, AÜEHFD, C. IV, S. 1-2 (2000), s. 355; EREN, N. 112, 115; KIRCA, s. 156157; KARABAĞ BULUT, s. 60-61.

6 EREN, N. 105; KARABAĞ BULUT, s. 66; AKÇAAL, Mehmet, Sözleşme Sonrası Sorumluluk, 1. Baskı, Mayıs 2018, s. 61. 
ya da malvarlığı değerlerine özen gösterme, zarar vermeme yükümlülügü altında olmasını ifade etmektedir?

Edim yükümlülüğü ile koruma yükümlülükleri arasındaki farkı belirtmek gerekirse; edim yükümlülüğü esas olarak sözleşmeden, başka bir deyişle taraf iradelerinden kaynaklanmaktayken, koruma yükümlükleri, TMK m. 2' de somut ifadesini bulan “dürüstlük kuralından" doğmaktadır9. Bu yönü ile koruma yükümlülükleri, kanuni bir borç ilişkisi meydana getirmektedir ${ }^{10}$. Yine edim yükümlülüğü ile koruma yükümlülükleri kaynakları itibariyle de farklılaşmaktadır. Edim yükümlülüğü, ancak hukuken geçerli bir şekilde kurulmuş olan bir sözleşmeden kaynaklanmaktayken, koruma yükümlülüğünün doğumu için bir sözleşmenin varlığ1 şart değildir. Bundan dolayı, herhangi bir sözleşmenin bulunmadı̆̆ı, henüz kurulmadığı, geçersiz veya sona ermiş olduğu durumlarda ya da üçüncü kişi ile olan ilişkilerde dahi koruma yükümlülükleri doğabilmektedir. Yeter ki taraflar arasında bir güven ilişkisi kurulmuş olsun ${ }^{11}$. Aralarında güven ilişkisi bulunan taraflar, birbirlerine karşı özenle davranma ve birbirlerinin mal ve şahıs varlıklarına zarar vermeme yükümlülüğü altında olduklarından ${ }^{12}$ söz konusu yükümlülüğün ihlali durumunda, oluşan zararın tazmini gerekmektedir ${ }^{13}$.

Koruma yükümlülükleri, sözleşme içeriğinden ve edimden bağımsız bir karakter göstermektedir. Bu yönü ile edim yükümlülükleri ile koruma yükümlülükleri birbirinden farklılaşmaktadır. Koruma

EREN, N. 106; KARABAĞ BULUT, s. 65; BROX/WALKER, s. 12.

8 Edim yükümlülükleri, esas olarak sözleşmeden doğar. Ancak kanundan ve dürüstlük kuralından kaynaklanan edim yükümlülükleri de söz konusudur. Edim yükümlülüklerinin kaynaklarına ilişkin olarak bkz. EREN, N. 95 vd.

9 EREN, N. 107; ANTALYA, Gökhan, Borçlar Hukuku Genel Hükümler Cilt: V/1, 1, Genişletilmiş 2. Baskı, Ankara 2019, N. 71.

10 HEHLI, Christoph, Die Alternativen Rechtsbehelfe des Käufers unter besonderer Berücksichtigung der Haftung aus Culpa in Contrahendo, Band 33, Zürich 2008, s. 151; EREN, N. 115.

11 OĞUZMAN/ÖZ, N. 138; FROST, Marina, Vorvertragliche und Vertragliche Schutzpflichten, Schriften zum Bürgerlichen Recht, Band 63, Ducker und Humolt/ Berlin 1981, s. 46.

12 KALKAN OĞUZTÜRK, s. 79; AKÇAAL, s. 61.

13 FROST, s. 40, 41; ANTALYA, Borçlar 1, N. 72. 
yükümlüğünün varlığı, edim yükümlülüğüne bağlı değildir ${ }^{14}$. Edim yükümlülüğü ve koruma yükümlülüğü ayrımı, doktrinde kabul edilen genel bir ayrımdır ${ }^{15}$.

\section{B. EDIMMDEN BAĞIMSIZ KANUNİ BORÇ İLIŞKİsi}

Koruma yükümlülükleri açısından, taraflar arasında, güven ilişkisinin başladığı ve devam ettiği sürenin belirlenmesi önem arz etmektedir. Güven ilişkisi, sözleşme öncesinde, sözleşmeden doğan borçların ifası aşamasında ve bu borçların ifasından sonra da mevcut olabilir. Bu durum, koruma yükümlülüklerine "edim yükümlülüğ̈ünden bağımsız kanuni borç ilişkisi" olma özelliğini vermiştir ${ }^{16}$.

Sözleşme görüşmeleri gerçekleştiren kimselerin “işlem temasına girmesi" ile işlem güvenliğinin sağlanması hususunda özel bir yükümlülük doğar. Bu yükümlülük taraflar arasında meydana gelen güven ilişkisinden kaynaklanır ${ }^{17}$. O hâlde, edim yükümlülügüunden bağımsız bir borç ilişkisinin varlığı, işlem temasının gerçekleşmesine bağlıdır. Bu açıdan kilit kavram olarak; işlem teması, tarafların hukuki bir işlem için karşılıklı etkileşime geçmelerini ifade etmektedir. İşlem teması ile birlikte taraflar, mal ve şahıs varlıklarını birbirlerinin etki alanına açmaktadırlar. Bu andan itibaren, tarafların, birbirlerinin kişilik değerlerine ve malvarlığına zarar verebilme ihtimali ve tehlikesi doğmaktadır. Bu safhada, her bir taraf, diğer tarafın kendisine zarar vermeyeceği ve makul, dürüst şekilde davranacağı yönünde bir güven beslemektedir. Bu güven, taraflara, birbirlerinin mal ve şahıs varlıklarına özen gösterme, zarar vermeme yükümlülüklerini de beraberinde getirmektedir. İşlem teması ile başlayan

$14 \quad$ FROST, s 13; KARABAĞ BULUT, s. 66.

15 EREN, N. 105 vd.; ANTALYA, Borçlar 1, N. 50 vd.; Ancak aydınlatma yükümlülüğü gibi bazı yükümlülükler, koruma yükümlülüğü olarak değerlendirilse de bazı durumlarda edim yükümlülügü kapsamına alınmış olabilir. Misal, 6502 sayılı Tüketicinin Korunması Hakkında Kanun m. 55'te düzenlenen ve esasında aydınlatma yükümlülüğü niteliği taşıyan tanıtma ve kullanma kılavuzu sunma yükümlügünün, yan edim yükümlülüğü teşkil edip etmeyeceği tartışılabilir.

16 SEROZAN, Rona, "Sözleşmenin müspet ihlali ve culpa in contrahendo", İstanbul Üniversitesi MHAD, No. 18, İstanbul 1990, s. 35,36; BAYGIN, s. 354; EREN, N. 111; KIRCA, s. 158; FROST, s. 40, 41; AKÇAAL, s.62, 63.

17 EREN, N. 106; KALKAN OĞUZTÜRK, s. 115; KIRCA, s. 170; KARABAĞ BULUT, s. 70; AKÇAAL, s. 61. 
bu yükümlülükler, sözleşmenin akıbetine tabi değildir; sözleşmenin geleceğinden bağımsız olarak mevcuttur ${ }^{18}$.

Edim yükümlülüğü, koruma yükümlülüğü ayrımı ve edimden bağımsız kanuni borç ilişkisi, modern hukukta kabul görmüş ve yerleşik bir hal almıştır. Hukukumuzda da edim yükümlülüğünden bağımsız borç ilişkisi teorisi, kabul görmektedir ${ }^{19}$. Ancak Yargıtay tarafından kabul görmüş ${ }^{20}$ ve uygulama alanı bulmuş olmasına rağmen konu hakkında genel normatif bir düzenleme halen mevcut değildir. Karşılaştırmalı hukuka bakıldığında, edim yükümlülügünden bağımsız borç ilişkisinin pozitif hukukta düzenlendiği bir örnek olarak Alman hukukunu görmekteyiz.

Almanya'da, 01.01.2002'de yürürlüğe giren Borçlar Kanunu'nun Modernleştirilmesine İlişkin Kanun (Schulrechtmodernisierung) ile edim yükümlülüğü, koruma yükümlülüğü ayrımı açıkça kabul edilmiştir. "Borç ilişkisinden doğan yükümlülükler" başlığını taşıyan ve iki fıkra hükmünden oluşan Alman Medeni Kanunu'nun (BGB) 241. maddesinin birinci fıkrasında edim yükümlülüğü; ikinci fıkrasında ise koruma yükümlülüğü düzenlenmiştir. Böylece edim yükümlülüğü ve koruma yükümlülüğü ayrımı açıkça ortaya konmuştur ${ }^{21}$. BGB 241/II “borç ilişkisi, içeriği açısından taraflara, birbirinin haklarına, hukuki değerlerine ve menfaatlerine saygı gösterme yükümlülü̈̆̈̈ yükler." demek suretiyle koruma yükümlülüklerini düzenlemiştir. BGB 311/II'de koruma yükümlülüklerini düzenleyen BGB 241/II'e atıf yapılarak koruma yükümlülüklerinden oluşan borç ilişkilerinin hangi hallerde gerçekleşeceği hüküm altına alınmıştır. BGB 311/II'ye göre, aşağıdaki hallerde koruma yükümlülüklerinden oluşan borç ilişkisi doğar²2:

SEROZAN, s. 38; BAYGIN, s. 355, 356; DEMİRCİĞLU, s. 128, 182; KALKAN OĞUZTÜRK, s. 85, 115.

19 ERGÜNE, Olumsuz Zarar, s. 109-111; AKÇAAL, s. 62.

20 Edim yükümlülüğünden bağımsız borç ilişkisine vurgu yapan kararlar için bkz. T.C. YARGITAY 22. HUKUK DAİRESİ E. 2017/20291 K. 2018/28025 T. 24.12.2018 (KAZANCI); T.C. YARGITAY HUKUK GENEL KURULU E. 2013/11-2425 K. 2015/2022 T. 30.9.2015 (KAZANCI); T.C. YARGITAY 13. HUKUK DAİRESİ E. 2009/12631 K. 2010/2398 T. 1.3.2010 (KAZANCI).

$21 \quad$ BROX/WALKER, s. 65, 66.

22 Hükmün çevirisi için ayrıca bkz. DEMİRCíĞLU, s. 69 ve 126. 
752 | Arş. Gör. Dr. Özkan ÖZYAKIŞIR / Arş. Gör. Muhammed K. GANBARİ

1. Sözleşme görüşmelerine başlamakla,

2. Sözleşme hazırlık aşamasında bir tarafin oluşan hukuki ilişki dolayısıyla diğer tarafin hakların, hukuki değerlerini ve menfaatlerini etkileyecek bir duruma gelmesi veya bu duruma güvenmesi ile,

\section{Benzer hukuki ilişki teması ile.}

Sözleşme görüşmelerine başlamakla koruma yükümlülüklerinin doğduğunu kabul eden Alman kanun koyucusu, böylece culpa in contrahendo sorumluluğunu normatif anlamda açıç̧a düzenlemiş bulunmak$\operatorname{tad}^{23}{ }^{23}$. Zira edim yükümlülüğünden bağımsız borç ilişkisinin en temel örneği esasen culpa in contrahendo sorumluluğudur ${ }^{24}$. Başkaca bir deyişle, bir sözleşmenin kurulması için görüşmelere başlayan taraflar, birbirlerine karşı koruma yükümlülüğü altına girmiş olurlar. Ayrıca taraflar arasından bu suretle edime bağlı olamayan bir borç ilişkisi de kurulmuş olur. İşte bu borç ilişkisi, culpa in contrahendo sorumluluğunu ifade etmektedir.

\section{SÖZLEŞME ÖNCESI GÖRÜŞME, GÖRÜŞMELERINN}

\section{KESILLMESI VE CULPA IN CONTRAHENDO}

\section{A. Sözleşme Öncesi Görüşme}

\section{Genel Olarak}

Sözleşmenin kurulması taraflar arasında belirli görüşmeleri zorunlu k1lan bir süreçtir. Mutlak bir zaruret olmamakla beraber sözleşme, bir anda ortaya çıkan bir hukuki işlem değildir. Sözleşme kurulmadan önce taraflar, sözleşmenin içeriği, şartları, içerdiği hak ve yükümlülükler üzerinde birbirleri ile görüşmeler yaparlar. Böylece "sözleşme öncesi görüşme" olarak adlandırılan hazırlık aşaması yaşanır²5.

Tarafların sözleşme görüşmelerine başlaması, görüşmeler sonucunda sözleşmenin meydana geleceği konusunda kesin bir durum yaratmaz. Bu yönü ile görüşmeler, sözleşmenin meydana gelmesini garanti

23 POHLMANN, s. 66; ERNEST-KÖLBL, s. 110; BROX/WALKER, s. 65, 84.

24 ANTALYA, Borçlar 1, N. 74; culpa in contrahendo sorumluluğunun hukuki niteliğine dair tartışmalar için bkz. HUGUENIN, Claire, Obligationenrecht- Allgemeiner und Besonderer Teil, Zürich 2012, N. 1530 vd.

25 EREN, N. 3529; HUGUENIN, N. 1525; POHLMANN, s. 67; BAYGIN, s. 345. 
etmemektedir ${ }^{26}$. Bu durum borçlar hukukuna hâkim en temel ilke olan sözleşme özgürlüğü ilkesinin tezahürüdür. Sözleşme özgürlüğü çerçevesinde kural olarak her birey, borç ilişkilerini dileği gibi, dilediği kişi ile kurabilmektedir. Sözleşme yapıp yapmama, sözleşmenin karşı tarafını seçme, sözleşmenin içeriğini belirleme ve kurulmuş olan bir sözleşmeyi ortadan kaldırma özgürlüğü, sözleşme özgürlügünün görünüm biçimleri olarak karşımıza çıkmaktadır²7.

\section{2. “Özel Hukuki Temas” Olarak Sözleşme Öncesi Görüşme}

Koruma yükümlülüklerini doğuran ve işlem teması olarak adland1rllan taraflar arasındaki bağ, basit sosyal bir temasın ötesinde anlam ifade etmektedir. Burada, tarafların hukuki değer ve menfaatlerini birbirlerinin etkisine ve özellikle diğer tarafın hâkim olduğu bir alana açması sonucunu doğuran özel hukuki bir temas söz konusudur ${ }^{28}$. Taraflar arasındaki temas tesadüfü değil; bir amaca yöneliktir. Bu amaç, tarafların aralarında daha sonra hukuki bir işlem yapma olasılıklarının bulunmasıdır ${ }^{29}$. Bu sebeple misal, bir mağazaya 1sınmak için giren kimse, sözleşme akdetme amacı taşımadığından mağaza sahibi ile aralarında özel hukuki temastan söz edilemez. O hâlde, söz konusu kişinin mağazada zarara uğraması durumunda, mağaza sahibinin culpa in contrahendo dolayısıyla sorumluluğu doğmaz ${ }^{30}$.

Özel hukuki temas, bir kimsenin sözleşmenin kurulmasının yönelik irade beyanın bulunup bulunmadığına bakılmaksızın hukuki menfaat alanına girilmesi ile oluşan ilişkidir ${ }^{31}$. Özel hukuki temas olarak

26 EREN, N. 3531; ERGÜNE, Olumsuz Zarar, s. 222; ANTALYA, Borçlar 1, N. 995.

27 REHM, Gebhard M., Aufkärungspflichten im Vertragsrecht, Münchener Universitätsschriften Reihe der Juristischen Fakultät, Band 179, München 2003, s. 106; MEDICUS, Dieter, Allgemeiner Teil des BGB, Heidelberg 1982, s. 70, 71; POHLMANN, s. 67; KAŞAK, Fahri Erdem, Sözleşme Özgürlüğünün Sınırı Olarak Kanunun Emredici Hükümlerine Aykırılık, İstanbul 2019, s. 56. Sözleşme özgürlügüne dair ayrımlar ve ayrıntılı açıklamalar için bkz. KAŞAK, s. 7 vd.

$28 \quad$ FROST, s. 53.

29 FROST, s. 59; HEHLI, s. 151-152.

30 DEMIRCIOĞLU, s. 185.

31 DEMIRCİĞLU, s. 85; KALKAN OĞUZTÜRK, s. 108. 
adlandırdığımız bu bağ, genel olarak "sosyal temas" kavramı ile de açıklanmaktadir ${ }^{32}$.

Tarafların sözleşme görüşmeleri, onların sözleşme öncesi giriştikleri ilk özel hukuki temastır ${ }^{33}$. Sözleşme öncesi görüşme evresinde taraflar, birbirlerinin egemenlik alanındadırlar ve bu egemenlik alanında bulunma durumu, taraflar arasında bir güven ilişkisi oluşturmaktadır. Söz konusu bu güven ilişkisi, özel ve somut bir hukukî bağ olarak karşımıza çıkmaktadır. Bu bağ, taraflara, birbirlerini olası zararlardan koruma yükümlülüğü yüklemektedir ${ }^{34}$.

\section{B. Culpa In Contrahendo ve Sözleşme Öncesi}

\section{Görüşmelerin Kesilmesi}

\section{Culpa In Contrahendo}

Özel hukuki temas, şu üç safhada mevcuttur: Bir sözleşmenin kurulması amacıyla tarafların bir araya gelmesi durumunda ilk özel hukuki temas gerçekleşir. Sözleşmenin kurulması ile başlayan hukuki ilişkide de taraflar arasında söz konusu temas mevcuttur. Bununla birlikte, ortada bir sözleşme ilişkisi olmadığı halde, kişinin can ve malvarlığı bir başka kişinin hukuki hâkimiyet alanının etkisinde ise yine özel hukuki temasın varlığından bahsedilir ${ }^{35}$. Buna göre, özel hukuki temas, sözleşme öncesinde, sözleşmenin ifası aşamasında ve sözleşmenin ifasından sonra da

32 FROST, s. 58; SEROZAN, s. 39; BAYGIN, s. 354; BROX/WALKER, s. 67.

33 BAYGIN, s. 345.

34 DEMİRCIOĞLU, s. 142-143, 183; ERGÜNE, Olumsuz Zarar, s. 115-116; MEDICUS, s. 156; BAYGIN, s. 345; “...sözleşme bir süreç olup, bir anda kurulup meydana gelen bir hukuki işlem değildir. Sözleşme kurulmadan önce de taraflar sözleşmenin muhtevası, şartları, içerdiği hak ve yükümlülükler üzerinde görüşmeler yapalar; bu görüşmeler kısa veya uzun sürebilir. Bu görüşmelerin başlamasıyla taraflar arasında sözleşme benzeri bir güven ilişkisi, diğer bir deyişle birbirlerinin kişilik ve mal varlı̆̆ de d̆erlerine zarar vermemek için gerekli özeni gösterme ve koruma yükümlülükleri doğar. Bu bağlamda, davacıya mağazada satın almak istediği eşyaların gösterilmesi isteği ve bu isteğin kabulü, bir icap-kabul niteliğinde olup, hukuksal işlem niteliğinde bir sonuç meydana getirmek amaçlanmaktadır. Bu aşamada davacının vücut bütünlüğ̈̈ne, davalı veya yardımcılar tarafindan verilen bu zararı, davalı sözleşme görüşmelerinden doğan sorumluluk uyarınca karşılamalıdır." (T.C. YARGITAY HUKUK GENEL KURULU E. 2010/13-593 K. 2010/623 T. 1.12.2010) (KAZANCI). 
taraflar arasında koruma yükümlülüklerinden oluşan bir borç ilişkisi doğurabilmektedir ${ }^{36}$.

Culpa in contrahendo sorumluluğu, yukarıda oluşum safhaları açıklanan özel hukuki temasın ilk aşaması ile ilgilidir. Zira culpa in contrahendo, sözleşme öncesi görüşmeler esnasında oluşan zarardan sorumluluk halini tanımlamaktadır ${ }^{37}$.

Bir sözleşmenin kurulması amacı ile bir araya gelen taraflar arasında özel bir hukuki temas mevcuttur ve bu temas, taraflar arasında güven ilişkisi doğurur ${ }^{38}$. Güven ilişkisi kurulduktan sonra artık taraflar, bu güven ilişkisinin gerektirdiği biçimde doğruluk ve dürüstlük kuralına uygun bir şekilde davranmak mecburiyetindedirler. Bu da aralarında güven ilişkisi bulunan taraflara, birbirlerinin kişilik ve malvarlı̆̆ı değerlerini korumada titiz davranmak ve dürüstlük kuralı gereğince özen göstermek zorunluluğunu getirmektedir ${ }^{39}$. Sözleşme görüşmeleri esnasında ortaya çıkan bu borç ilişkisi, edimden bağımsızdır ve sadece koruma yükümlülüklerinden oluşmaktadır. Sözleşme öncesi tarafların bu yükümlülüklere aykırı davranışı, culpa in contrahendo sorumluluğg olarak nitelendirilmektedir ${ }^{40}$.

Culpa in contrahendo öğretisi, ilk olarak geçersiz sözleşmeler ile tamamlanmamış sözleşme görüşmeleri açısından savunulmuştur ${ }^{41}$.

36 HEHLI, s. 151.

37 BÜYÜKSAĞİŞ, Erdem, Yeni Sosya- Ekonomik Boyutuyla Maddi Zarar Kavramı, İstanbul 2007, s. 123; GONZENBACH, Rainer, Culpa in Contrahendo im schweizerischen Vertaragsrecht, Bern 1987, s. 3; HEHLI, s. 181.

38 “Bu sebeple sözleşme yapmak amacı ile sosyal temasa giren kişiler bu andan itibaren aralarında kurulan ilişkinin her safhasında birbirlerine zarar vermemek için her türlü özeni göstermek, gerekli çabayı sarf etmek zorundadırlar. Örneğin: Alışveriş yapmak üzere mağazaya gelen müşterinin hırsızlık olaylarına karşı korunması veya merdivenlerden düşme tehlikesinin önlenmesi ile ilgili gerekli koruma tedbirlerinin ilgili işyeri tarafindan alınması zorunludur." (T.C. YARGITAY 13. HUKUK DAİRESİ E. 2010/2762 K. 2010/12361 T. 29.9.2010) (KAZANCI).

39 EREN, N. 3529; HUGUENIN, N. 1548; BAYGIN, s. 345.

40 HEHLI, s. 150; GONZENBACH, s. 7; SEROZAN, s. 39; OĞUZMAN/ÖZ, N. 1550; BAYGIN, s. 345-346.

41 HEHLI, s. 143; DEMIRCİĞLU, s. 54; KALKAN OĞUZTÜRK, s. 86-87; FROST, s. 43; POHLMANN, s. 37; BAYGIN, s. 346; tarihi gelişim için bkz. GÜVENÇ, Özgür, "Culpa in Contrahendo Sorumluluğu Bağlaminda Sözleşme Görüşmelerinin Kesilmesi", Gazi Üniversitesi Hukuk Fakültesi Dergisi C. XVIII, Y. 2014, S. 3-4, s. 365 vd. 
Taraflardan birinin kusuru yüzünden sonuçlanmayan (kurulamayan) veya geçersiz olarak meydana gelen sözleşmelerde, kusuru ile bu duruma sebebiyet veren tarafın, meydana gelen zarar dolayısıyla sorumluluğuna kanunda uygulanabilir bir hükmün bulunmaması üzerine "culpa in contrahendo" sorumluluğu keşfedilmiştir. Bu doğrultuda, culpa in contrahendo sorumluluğunun uygulama alanı, hiç kurulmamış ya da geçersiz olan sözleşmeler ile sinırlı tutulmuştur ${ }^{42}$.

Tarihi süreç içerisinde yaşanan gelişmeler, culpa in contrahendo sorumluğunun, sınırlı uygulama alanını genişletmiştir ${ }^{43}$. Zaman içerisinde culpa in contrahendo sorumluluğu, sadece geçersiz sözleşmeler açısından değil; ayrıca geçerli olarak kurulmuş sözleşmelerin görüşme safhasında meydana gelen zararlarda ${ }^{44}$ da uygulama alanı bulmuştur ${ }^{45}$. Misal, bir sözleşmeyi aldatma sonucunda imzalayan kimse, sözleşmeyi iptal etmemekle birlikte aldatma sebebiyle uğradığ zararları culpa in contrahendo esasına göre talep edebilir ${ }^{46}$. Ayrıca culpa in contrahendo sorumluluğu, hiçbir hukuki işlem sonucunu doğurmayan sözleşme öncesi görüşmeler sırasında meydana gelen zarardan sorumluluk halini de kapsayan bir sorumluluk türü olarak karşımıza çıkmaya başlamıştır ${ }^{47}$.

Bir tarafın hukuki menfaatini ya da bir hakkını, özel hukuki temasa girildiği andan itibaren koruma gerekliliği görüşü ${ }^{48}$ aslında tam da culpa in contrahendo sorumluluğunu ifade etmektedir. Çünkü sözleşme öncesi görüşmeler, özel temasa girişilen ilk andır. Bu andan itibaren tarafların mal ve şahıs varlığı hukuken koruma altında olmalıdır ${ }^{49}$. Bundandır ki günümüzde culpa in contrahendo, sözleşme öncesi görüşmeler

42 346.

43 124.

EREN, N. 3530; KIRCA, s. 160-161; FROST, s. 43; POHLMANN, s. 38; BAYGIN, s.

Tarihi süreç içerisinde yaşanan gelişmeler için bkz. DEMİRCiOĞLU, s. 54 vd.; GÜVENÇ, s. 365 vd.

HUGUENIN, N. 1535.

Aksi görüşte bkz. KUTLU SUNGURBEY, Ayfer, Yetkisiz temsil Özellikle Culpa in Contrahendo - Sözleşme Görüşmesinde Kusur ve Olumsuz Zarar, İstanbul 1988, s.

Bkz. DEMİRCIOĞLU, s. 217.

GONZENBACH, s. 6, 7; POHLMANN, s. 37-38.

Bu hususta bkz. KALKAN OĞUZTÜRK, s. 115.

FROST, s. 14. 
sırasındaki borç ilişkisine aykırı davranış hali olarak görülmektedir. Bu borç ilişkisi, tarafların birbirlerine karşı dürüstlük kuralı gereğince genel bir özen gösterme yükümlülüğünün oluşturduğu; özel hukuki temas sonucunda meydana gelen güven ilişkisinden kaynaklanmaktadır. Bu güven ilişkisinden sorumluluk doğması gerektiği tartışmasız suretle kabul edilmektedir ${ }^{50}$.

Culpa in contrahendo, Alman hukukunun aksine Türk ve İsviçre hukukunda münferit bir yasa maddesi olarak düzenlenmemiş ve TMK m. 2 kaynaklı olarak kabul edilmiştir ${ }^{51}$. Fakat münferit bazı hükümlerde culpa in contrahedo sorumluluğunun esasını teşkil eden unsurlar mevcuttur ${ }^{52}$. TBK m. 47/I, c. 1'e göre “Temsil olunanın açık veya örtülü olarak hukuki işlemi onamaması hâlinde, bu işlemin geçersiz olmasından doğan zararın giderilmesi, yetkisiz temsilciden istenebilir." Bu ihtimalde, yetkisiz temsilci ile sözleşmenin kurulmamasından dolayı zarara uğrayan kişi arasındaki sorumluluk, culpa in contrahendo esasına dayanmaktadır ${ }^{53}$. Ayrıca culpa in contrahendo sorumluluğu, doktrin ve uygulamada da açıkça kabul edilmiştir ${ }^{54}$.

50 DEMİRCIOĞLU, s. 75; KALKAN OĞUZTÜRK, s. 100; BÜYÜKSAĞİş, s. 124.

51 KIRCA, s. 139-142; AKÇAAL, s. 73; Taraflar arasındaki uyuşmazlık, bayilik sözleşmesi imzalanacă̆ inanç ve düşüncesi ile yapılan harcamalara ilişkin tazminat isteminden kaynaklanmaktadır. Başka bir anlatımla talebin dayană̆ı "akit görüşmelerinden doğan sorumluluk" (CULPA IN CONTRAHENDO) kuralıdır. Akit bir süreçtir. Taraflar akit kurulmadan önce akdin içeriği, şartları içerdiği hak ve yükümlülükler üzerinde görüşmeler yapar. Bu görüşmelerin başlaması ile taraflar arasında hukuki ilişki kurulur. Bu ilişki akit benzeri bir güven ilişkisidir ve (MK.2/1) de düzenlenen dürüstlük kuralına dayanır. Buna göre taraflar görüşmeler esnasında akdin içeriği ve şartları hakkında birbirlerini aydınlatması dürüstlük kuralına uygun davranması, birbirlerinin kişilik ve mal varlığı değerlerine zarar vermemek için gerekli özeni göstermesi gerekir. Taraflar bu yükümlülüklerine kusurlu olarak aykırı davranıp görüşmelerin başlaması ile aralarında kurulmuş bulunan güven ilişkisini ihlal ettikleri takdirde bundan doğan zarardan sorumludurlar." (T.C. YARGITAY 19. HUKUK DAİRESİ E. 2005/2865 K. 2005/11959 T. 1.12.2005) (KAZANCI); İsviçre Federal Mahkemesi de söz konusu sorumluluğunun kaynağını dürüstlük kuralına dayandırmaktadır, bu yöndeki karar için bkz. BGE 105 II 75 S. 79.

52 HUGUENIN, N. 1529; ANTALYA, Borçlar 1, N. 1002; DEMIRCİOĞLU, s. 73; BÜYÜKSAĞİş, s. 123; BAYGIN, s. 358.

53 ANTALYA, Borçlar 1, N. 2592.

54 TANDOĞAN, Haluk, Türk Mesuliyet Hukuku, Ankara 1961, s. 403-404; "Kaldı ki, dava dilekçesinde sözleşmenin ifa edilmemesi yanında sözleşmenin kurulacağı ve ifa edileceğine güvenilerek sözleşme öncesi görüşmelerden doğan sorumluluğa da dayanılmıştır. 
758 | Arş. Gör. Dr. Özkan ÖZYAKIŞIR / Arş. Gör. Muhammed K. GANBARİ

\section{Sözleşme Öncesi Görüşmelerin Kesilmesi Meselesi}

\section{a. Genel Olarak Sözleşme Öncesi Görüşmelerin Kesilmesi}

Yukarıda ifade edildiği üzere sözleşme öncesi görüşme, sözleşmenin meydana gelmesi açısından bir hazırlık safhası olarak görülmektedir. Sözleşme görüşmelerinin amacı, tarafların sözleşme yapıp yapmama kararının oluşmasına katkıda bulunmak üzere sözleşmenin faydalı ve elverişsiz yanlarını ortaya koymaktır ${ }^{55}$. Bu safhada taraflar, sözleşme özgürlüğü gereğince sözleşme yapıp yapmamakta serbesttirler ${ }^{56}$. Bu durum, kural olarak taraflara dilediği anda sözleşme görüşmelerinden çekilme imkânı vermektedir. Tarafların sahip olduğu bu imkân, sözleşme özgürlüğü ilkesinin doğal bir sonucudur. Fakat tarafların sözleşme özgürlüğü çerçevesinde bir hukuki işlemi yapıp yapmamak hususunda serbest

Doktrinde "culpa in contrahendo" olarak adlandırılan bu tür sorumluluğun da tazminat talebine dayanak yapılabileceği kuşkusuzdur. "(T.C. YARGITAY 19. HUKUK DAİRESİ E. 2005/1932 K. 2005/4790 T. 28.4.2005) (KAZANCI); benzeri yönde bkz. “Oysa; sav savunma, toplanan delil ve belgelerin ışı̆̆ında bir değerlendirme yapıldığında olaya "akit görüşmelerinden doğan sorumluluk" (CULPA IN CONTRAHENDO) kurallarıla bakılması gerektiğinde kuşku ve duraksamaya yer olmamahdır. Gerçekte de akit bir süreçtir. Bir anda kurulup meydana gelen hukuki bir işlem değildir. Akit kurulmadan önce taraflar; aktin muhtevası, şartları içerdiği hak ve yükümlülükler üzerinde görüşmeler yaparlar; bu görüşmeler kısa veya uzun sürebilir. Görüşmelerin başlamasıyle görüşmeciler arasında hukuki bir ilişki kurulur. Bu ilişki akit benzeri bir güven ilişkisidir. Güven ilişkisi MK. md. 2/1'de düzenlenmiş bulunan dürüstlük kuralına dayanır. Buna göre görüşmeler esnasında, görüşmecilerin akdin muhtevası ve şartları hakkında birbirlerini aydınlatması dürüstlük kuralına uygun davranması, birbirlerinin kişilik ve mal varlığı değerlerine zarar vermemek için gerekli özeni göstermesi, koruma yükümlülüklerine uyması gerekir. Görüşmeciler bu yükümlülüklere kusurlu olarak aykırı davranıp görüşmelerin başlamasıyla aralarında kurulmuş bulunan güven ilişkisini ihlal ettikleri takdirde bundan doğan zarardan sorumludurlar (Bk. Prof. Dr. Fikret Eren, Borçlar Hukuku Genel Hükümler, Cilt: III, Ankara-1990, Sh. 306 vd.). Yanlar arasında sözleşmenin kurulması sırasında belirlenen maddi olgular açıklanan hukuk kuralları ışığında değgerlendirildiğinde davacı Yüksel'in öğretmen olduğunu, o nedenle ticaretle iştigal edemeyeceğini davalıya bildirmemekle dürüstlük kuralına uygun davranmadı̆̆ının kabulü kaçınlmaz olmaktadır. O nedenle, sözleşme görüşmelerinin başlamasıyla vücut bulan güven ilişkisini anılan davacı ihlal ettiğinden, bundan doğan zarardan da sorumlu olduğunun kabulünde kuşku ve duraksamaya yer olmamalıdır." (T.C. YARGITAY 13. HUKUK DAİRESİ E. 1995/9375 K. 1995/9860 T. 13.11.1995) (KAZANCI). 
olmaları, tarafların sözleşme öncesi görüşmeler sırasında birbirlerine karşı olan koruma yükümlülüklerini ortadan kaldırmaz ${ }^{57}$.

Sözleşme görüşmelerinin başlaması ile taraflar arasında hukuki bir ilişki kurulmuş olur. Bu ilişki, her ne kadar hukuki işlem olmasa da sözleşme benzeri bir güven ilişkisidir ${ }^{58}$. Müzakere eden bu kişiler arasındaki güven ilişkisi, TMK m. 2' de düzenlenmiş bulunan dürüstlük kuralı gereğince görüşmecilere koruma yükümlülükleri yükler ${ }^{59}$.

Tüm bu hususlar, dürüstlük kuralının sözleşme özgürlüğü ilkesine getirilmiş bir sınır olduğunu ortaya koymaktadır. Buna göre; taraflar, sözleşme özgürlüğü ilkesinin kendilerine tanıdığı imkânları kullanırken dürüstlük kuralına uygun davranmakla yükümlüdürler ${ }^{60}$. Bu yükümlülüğe aykırı davranış, tazminat sorumluluğu doğurur ${ }^{61}$.

\section{b. Sözleşme Öncesi Görüşmelerin Kesilmesi Bakımından Culpa In Contrahendo Sorumluluğu}

İrade serbestisi ilkesi gereğince ifade edildiği üzere sözleşme görüşmelerine başlayan kimsenin, amaçlanan sözleşmeyi mutlaka yapma

57 MEDICUS, s. 159; REHM, s. 152,154,187; POHLMANN, s. 151; GONZENBACH, s. 95-96; ERNEST-KÖLBL, s. 113.

58 ANTALYA, Borçlar 1, N. 974.

59 EREN, N. 3529; MEDICUS, s. 156; FROST, s. 40; BAYGIN, s. 345; “Gerçekte de; sözleşme bir süreçtir. Bir anda kurulup meydana gelen hukuki bir işlem değildir. Sözleşme kurulmadan önce taraflar sözleşmenin muhtevası, şartlarl, içerdiği hak ve yükümlülükler üzerinde görüşmeler yaparlar; bu görüşmeler kısa veya uzun sürebilir. Görüşmelerin başlamasıyla görüşmeciler arasında hukuki bir ilişki kurulur. Bu ilişki sözleşme benzeri bir güven ilişkisidir. Güven ilişkisi MK. m. 2/1'de düzenlenmiş bulunan dürüstlük kuralına dayanır. Buna göre görüşmeler esnasında görüşmecilerin sözleşmenin muhtevası ve şartları hakkında birbirlerini aydınlatması, dürüstlük kuralına uygun davranması, birbirlerinin kişilik ve mal varlığı değerlerine zarar vermemek için gerekli özeni göstermesi, koruma yükümlülüklerine uyması gerekir. Görüşmeciler bu yükümlülüklere kusurlu olarak aykırı davranıp, görüşmelerin başlamasıyla aralarında kurulmuş bulunan güven ilişkisini ihlal ettikleri takdirde bundan doğan zarardan sorumludurlar (Fikret Eren, a.g.e., s. 1084, 306 vd., İhan Ulusan, a.g.e., s. 286)" (T.C. YARGITAY 22. HUKUK DAİRESİ E. 2017/20291 K. 2018/28025 T. 24.12.2018) (KAZANCI).

60 HUGUENIN, N. 1525, 1527; BGE 80 II 26 S. 43.

61 MEDICUS, s. 156; GONZENBACH, s. 15; ERNEST-KÖLBL, s. 116; BGE 132 III 24 S. 31. 
zorunluluğu bulunmamaktadır ${ }^{62}$. Bu nedenle sözleşme görüşmelerinin yarıda kesilmiş olması, kural olarak bir sorumluluk nedeni oluşturmaz ${ }^{63}$. Zira görüşmeler aşamasında ortaya çıkan hukuki ilişki, henüz bir kesinliğe ulaşmış değildir. Bu evrede sözleşme görüşmelerine başlayan herkes, bu görüşmelerin yarıda kesilebileceğini hesaba katmak zorundadır ${ }^{64}$. Sözleşme serbestisi bunu gerektirmektedir. Fakat bu serbesti taraflara sınırsız bir özgürlük alanı sunmamaktadır. Taraflar bu bağlamda dürüstlük kuralından doğan koruma yükümlülüklerine her evrede riayet etmelidirler ${ }^{65}$.

Sözleşme görüşmelerinin kesilmesi, kural olarak tazminat sorumluluğuna yol açmamaktadır. Sözleşme görüşmelerine başlanmış fakat görüşmeler bir tarafin objektif haklı bir nedene dayanmayan davranışı sonucu kesilmiş olabilir. Sözleşme yapılacağına dair uyandırılan güvenin bu şekilde boşa çıkarılmış olduğu durumlarda uğranılan zararlar, TMK $\mathrm{m}$. 2 bağlamında tazmin edilmelidir. Dürüstlük kuralı bunu gerektirmektedir ${ }^{66}$.

Tazminat yükümlülüğü, görüşmeleri kesen tarafın karşı tarafta uyandırdığı güveni ağır biçimde ihlal ettiği ya da sözleşme yapma niyeti olmaksızın diğer görüşmeciye zarar vermek amacıyla hareket ettiği hallerde ortaya çıkar. Burada zarar, sözleşmenin yapılmamış olmasından kaynaklanmamaktadır. Zarar sözleşme yapma niyeti bulunmayan ya da görüşmeleri yarıda kesen tarafın, karşı tarafta uyandırdığı güvenin boşa çıkması sonucunda gerçekleşmektedir ${ }^{67}$.

Sözleşme görüşmelerinin yarıda kesilmesinin herhangi bir sorumluluk doğurup doğurmayacağı, yukarıdaki esaslar çerçevesinde somut olayın özelliklerine göre belirlenir. Şöyle ki görüşmeleri bir sözleşme

62 EREN, N. 3531; DEMIRCIOĞLU, s. 195; ERGÜNE, Olumsuz Zarar, s. 222; KALKAN OĞUZTÜRK, s. 98; ANTALYA, Borçlar 1, N. 995.

63 GÜVENÇ, s. 371.

64 Hatta bu süreçte ortaya çıkan bütün zaman ve maddi kayıplara da kural olarak tarafların kendileri katlanacaktır. Bu yönüyle culpa in contrahendo sorumluluğu özel şartlara bağlı istisnai bir sorumluluktur, bkz. HUGUENIN, N. 1540.

65 DEMIRCIOĞLU, s. 194-195; EREN, N. 3529; ERGÜNE, Olumsuz Zarar, s. 222-223.

66 DEMİRCIOĞLU, s. 194-195; KALKAN OĞUZTÜRK, s. 94; HUGUENIN, N. 15411542; POHLMANN, s. 153, 154; GONZENBACH, s. 15, 97. KÖLBL, s. 116. 
kurmaksızın sona erdirme serbestisi ile görüşmelerin dürüstlüğe aykırı biçimde yarıda kesilmesi yasağı arasında teorik açıdan bir sınır vardır. Bu sınır, her somut olayda müzakerelerin yoğunluğu, tarafların müzakereler için yaptığı tasarruflar ve benzeri kendine özgü koşullar değerlendirilerek tespit edilirir8. Söz gelimi taraflar, şekle tabi olan taşınmaz satış sözleşmesinin kurulmasına dair görüşmeler sırasında esaslı noktalarda mutabakat sağlamıştır. Aynı zamanda tarafların, sözleşmenin imzalanması için gerekli hazırlıkları da yapmış olduklarını farz edelim. Bu sırada taraflardan biri, sözleşmeyi imzalamaktan gerekçesiz olarak kaçınmış ve görüşmeleri yarıda kesmiş olsun. Böylesi bir olayda, görüşmeyi yarıda kesen taraf, görüşmenin kesilmesi sebebiyle uğranılan zararı tazmin etmekle yükümlüdür ${ }^{69}$. Hâlbuki misalde, bedel hususunda irade uyuşmasının sağlanamaması sebebiyle görüşmelerin kesilmesi durumunda, tazminat sorumluluğu söz konusu olmaz. Her durumda sözleşme görüşmelerini sona erdirme serbestisi ile görüşmelerin dürüstlüğe aykırı biçimde yarıda kesilmesi yasağı arasındaki teorik sınırı hâkim belirler.

Sözleşme görüşmelerine katılanlar, görüşmelerin gelişimini dikkate alarak birbirlerine sözleşmenin kurulma, uygulama ve sona erme koşulları ile ilgili doğru bilgi vermelidirler. Ayrıca bilgisizlik veya yanlış anlaşılma sonucu ortaya çıkabilecek yanılgıları ortadan kaldırmakla da yükümlüdürler. Hakeza taraflar, sözleşme öncesi görüşmeler evresinde birbirlerine karşı doğru, dürüst bir kişinin göstereceği özeni göstermek zorundadırlar. Görüşmecilerin, dürüstlük kuralına uygun davranması, birbirlerinin şahıs ve malvarlığı değerlerine zarar vermemek için gerekli özeni göstermesi gerekmektedir ${ }^{70}$.

68 HUGUENIN, N. 1528; ERGÜNE, Olumsuz Zarar, s. 224; POHLMANN, s. 153; GONZENBACH, s. 97; BROX/WALKER, s. 301.

69 Benzeri şekilde bir Alman Federal Mahkemesi kararı için bkz. BÜYÜKSAĞìş, s. 128.

70 EREN, N. 3529; KALKAN OĞUZTÜRK, s. 94; BÜYÜKSAĞİş, s. 124; KARABAĞ BULUT, s. 66-67; MEDICUS, s. 156; REHM, s. 189; BAYGIN, s. 354, 356; BROX/WALKER, s. 301. 
762 | Arş. Gör. Dr. Özkan ÖZYAKIŞIR / Arş. Gör. Muhammed K. GANBARİ

\section{OLUMSUZ ZARAR VE ZARARIN KAPSAMI}

\section{A. Genel Olarak Zarar Kavramı}

Zarar, kelime anlamı itibarıyla "bir kimse veya şeyin sebep olduğu kayıp, kötü sonuç, ziyan" olarak tanımlanmaktadır ${ }^{71}$. Günlük hayatta kullanılan anlam bu olmakla birlikte, çalışmamız açısından zararın hukuki bir kavram olarak neyi ifade ettiği önem arz etmektedir. Zarar, nitelik ve kapsam bakımından ortaya çıktığı hukuki ilişkiye göre değişiklik gösterir ${ }^{72}$. Bu özelliği, zarar kavramına, kanunî bir tanımın yapılamaması sonucunu doğurmuştur. Bu durum, Türk/İsviçre hukuk sisteminde olduğu gibi Alman hukuk sisteminde de geçerlidir. Sonuç olarak bahsi geçen hukuk sistemleri, zarar kavramına kanuni bir tanım getirmekten kaçınmıştır ${ }^{73}$.

Zarar kavramı için kanuni bir tanımın getirilmemesi, aynı zamanda kanun koyucunun bilinçli bir tercihi olarak karşımıza çıkmaktadır. Bilinçli kaçınma hali, yapılabilecek bir tanımın sürekli değişen ihtiyaçlara cevap verememesi endişesinin ürünüdür. Böylece her hukuki ilişkinin yapısına göre değişken bir yapı arz eden zarar kavramının içini doldurma işi, doktrin ve yargı kararlarına bırakılmıştır ${ }^{74}$. Kavram, doktrinde kendine bağlanan hukuki sonuçlara göre çeşitli ayrımlara tabi tutulmaktadır ${ }^{75}$. Olumlu- olumsuz zarar, doğrudan- dolaylı zarar, maddi- manevi zarar gibi ayrımlar ilk göze çarpan tasniflerdir.

\section{B. Olumsuz Zarar}

\section{Genel Olarak}

Olumsuz zarar, sözleşmenin kurulmasına veya geçerliliğine yahut ifasına ilişkin olarak karşı tarafta uyandırılan güvenin boşa çıkarılması

71 AYVERDİ, İlhan, Misalli Büyük Türkçe Sözlük, İstanbul 2010, s. 1378; YILDIRIM, Fadıl/BAŞPINAR, Veysel, “Doktrin ve Uygulama Açısından Türk-İsviçre Hukukunda Doğrudan Doğruya ve Dolaylı Zarar Ayrımı", Prof.Dr. Bilge Öztan'a Armağan, Ankara 2008, s. 1094.

72 BÜYÜKSAĞİş, s. 45.

73 Aynı yönde bkz. LANGE, Hermann, Handbuch des Schuldrecht, Schadensersatz, 2. Auflage, Tübingen, 1990, s. 27, 28.

74 ERGÜNE, Olumsuz Zarar, s. 8; LANGE, s. 28, 37.

75 Bkz. TANDOĞAN, s.69 vd.; OĞUZMAN/ÖZ, N. 1265 vd. 
nedeni ile oluşan zarar olarak nitelendirilmektedir ${ }^{76}$. Başka bir deyişle, esasen hüküm ifade etmeyen borç ilişkisinin geçerli surette kurulduğuna yahut kurulacağına veya geçersizliğin bilinmesine rağmen ifa edileceğine dair oluşturulan haklı güven sebebi ile meydana gelen zarar, olumsuz zararı oluşturur. Bu sebeple, olumsuz zararı diğer zararlardan ayıran en önemli özelliğin, zarar verici olayın, uyandırılan güvenin boşa çıkarılması tarzında meydana gelmesi olduğu ifade edilmektedir ${ }^{77}$.

Güven sorumluluğu durumunda haklı güvenin boşa çıkması nedeni ile meydana gelen zararın tazmini söz konusudur ${ }^{78}$. Olumsuz zarar da güven sorumluluğundan kaynaklanan güven zararının bir görünüm biçimi olarak karşımıza çıkmaktadır ${ }^{79}$. Sözleşme görüşmeleri ya da sözleşmenin kurulması aşamasında ortaya çıkan olumsuz zarar, güven zararının somut bir uygulama örneğidir. Ne var ki güven zararı, sadece sözleşme görüşmeleri evresinde söz konusu olan culpa in contrahendo sorumluluğundan ibaret değildir. Çünkü güven sorumluluğu, sadece sözleşme görüşmeleri aşamasında değil, sözleşmenim kurulması ve sonrasinda da söz konusu olan bir üst kavramdır ${ }^{80}$. Buna göre olumsuz zararın, güven zararının bir alt başlığı olduğu söylenebilir" ${ }^{81}$

\section{Culpa In Contrahendo ile Olumsuz Zarar İlişkisi}

Zarar türleri açısından yapılan tasnife göre culpa in contrahendo kaynaklı sorumluluk halinde hangi nevi zararın tazmininin gerektiği de değerlendirilmelidir. Sözleşme öncesi görüşmelerin kesilmesi nedeni ile uğranılan zarar, taraflardan birinin amaçlanan sözleşme ile hukuken bağlanacağına inanması ve bu inanışın boşa çıkması sebebi ile gördüğü

76 TANDOĞAN, s. 427; OĞUZMAN/ÖZ, N. 1268; ANTALYA, Gökhan, Borçlar Hukuku Genel Hükümler Cilt: V/1, 3, Genişletilmiş 2. Bask1, Ankara 2019, N. 3014; YILDIRIM/BAŞPINAR, s. 1096-1097; “Menfi zarar uygulanacă̆ına ve yerine getirileceğine inanılan bir sözleşmenin yerine getirilmemesi sonucu güvenin boşa çıkması nedeniyle uğranılan, sözleşme yapılmasaydı uğranılmayacak olan zarardır." (T.C. YARGITAY 15. HUKUK DAİRESİ E. 2019/2120 K. 2019/4525 T. 12.11.2019) (KAZANCI).

77 YILDIRIM/BAŞPINAR, s. 1097; DEMIRCİĞLU, s. 263-264; ERGÜNE, Olumsuz Zarar, s. 39; BAYGIN, s. 362.

78 KIRCA, s. 136; DEMİRCİĞLU, s. 162; KALKAN OĞUZTÜRK, s. 53, 60.

79 ANTALYA, Borçlar 3, N.1908-1909.

80 KIRCA, s. 137; ERGÜNE, Olumsuz Zarar, s. 48.

81 GONZENBACH, s. 199. 
zarardır. Bu tür zararlar, olumsuz zarar olarak nitelendirilmektedir ${ }^{82}$. Bu sebeple culpa in contrahendo sorumluluğunun var olduğu hallerde kural olarak olumsuz zarar tazmin edilir83. Zira sözleşme görüşmelerinin kesilmesi sonucu oluşan zarar, taraflardan birinin amaçlanan sözleşme ile bağlanacağına olan inancının boşa çıkarılmasından kaynaklanmaktadır ${ }^{84}$.

Culpa in contrahendo sorumluluğunun bulunduğu durumlarda kural olarak olumsuz zararın tazmini genel kabul görmektedir ${ }^{85}$. Ancak münferit olarak culpa in contrahendo sorumluluğunu düzenleyen bazı kanun hükümleri, istisnai hallerde olumlu zararın tazminine de imkân sağlamaktadır ${ }^{86}$. Misal, TBK m. 47/II uyarınca hakkaniyet gerektiriyorsa, kusurlu yetkisiz temsilci, sözleşmenin kurulmaması sebebiyle zarar görenin diğer zararlarını, olumlu zararlarını da gidermekle yükümlüdür. Ayrıca doktrinde bir görüş, bu hükümlerden hareketle hakkaniyet gerektiren herhâlde culpa in contrahendo sorumluluğu kapsamında da olumlu zararın giderilmesi gerektiğini savunmaktadır ${ }^{87}$. Bu görüşe göre de culpa in contrahendo sorumluluğu durumunda kural olarak olumsuz zararın talep edilmesi gerekir. Ancak hakkaniyet gerektiriyorsa, hâkim olumlu zarara hükmetmek noktasında takdir hakkına sahiptir. Yine doktrinde bir görüş, culpa in contrahendo sorumluluğunun bulunduğu her durumda

OĞUZMAN/ÖZ, N. 1270; YILDIRIM/BAŞPINAR, s. 1097; ERGÜNE, Olumsuz Zarar, s. 39-40, 118; LANGE, s. 65.

83 HUGUENIN, N. 1554; İsviçre Federal Mahkemesi de culpa in contrahendo sorumluluğu durumunda olumsuz zararın tazmininin gerektiği görüştedir, bu yönde bkz. BGE 105 II 75 S. 81.

84 GONZENBACH, s. 199; DEMIRCIOĞLU, s. 264; BAYGIN, s. 362-363.

85 Culpa in contrahendo sorumluluğu kapsamında bedensel ve malvarlığı zararlarının giderilip giderilmeyeceği tartışmalıdır. Bu noktada kimi yazarlara göre beden ve malvarlığına yönelik zararlarda haksız fiile başvurmak gerekmekte olup, culpa in contrahendo yalnız salt ekonomik zararlar içindir. Bkz. HUGUENIN, N. 1550; Culpa in contrahendo sorumluluğunun salt ekonomik zararlar dışında bedensel ve malvarlığı zararlarını da kapsadığı yönünde bkz. DEMİRCİĞLU, s. 246-247; BÜYÜKSAĞiş, s. 125-126.

86 Bkz. ERGÜNE, Mehmet Serkan, “Culpa in Contrahendo Sorumluluğunda Olumlu Zararın Tazmini”, Prof. Dr. Rona Serozan'a Armağan, C. I, İstanbul 2010, s. 917 vd.

87 HUGUENIN, N. 1555; ERGÜNE, Culpa in Contrahendo, s. 919, yazar bu noktada kanunda culpa in contrahendo olarak nitelendirilebilecek hallerde açıça olumlu zararın tazminine imkân veren hükümlerin kıyasen uygulanmasını savunmaktadır. 
olumlu zararın tazmininin gerektiğini savunmaktadır ${ }^{88}$. Bu görüşü göre, culpa in contrahendo sorumluluğunun var olduğu hallerde tıpkı TBK m. 112 ' de olduğu gibi olumlu zararın tazmini yoluna gidilmelidir.

\section{Olumsuz Zararın Kapsamı}

\section{Genel Olarak}

Borçlunun fiili dolayısıyla zarar gören kimsenin uğradığı olumsuz zararın hesaplanmasında en önemli husus, zararın kapsamının ortaya konulmasıdır. Zarar görenin, bir başka deyişle tazminat alacaklısının, zarar verici olay hiç olmasaydı içinde bulunacağı durumunun yeniden tesisi olumsuz zararın tazmini ile gerçekleşmektedir ${ }^{89}$. Olumsuz zarar, sözleşmesel alana dair olup ${ }^{90}$ ancak bu bağlamında tartışılabilen bir zarar türüdür. Cismani bütünlüğe veya doğrudan malvarlığı değerlerine yönelik ihlaller neticesinde ortaya çıkan zararlar, bu kavramın dışındadır ${ }^{91}$.

Bir borç ilişkisinin hükümsüzlügü yüzünden, bu borç ilişkisine güvenen kimsenin malvarlığının aldığ fiili durum ile güvenen kimsenin malvarlığının, zarar verici olay hiç gerçekleşmeseydi içinde bulunacağı farazi durum arasındaki fark, uğranılan olumsuz zarar miktarını vermektedir ${ }^{92}$. Bir başka deyişle, esas olarak; kendisinde bir sözleşmenin kurulacağına yönelik güven uyandırılan kimsenin, sözleşmenin kurulması, borçların ifası ve oluşan fiili durumun tasfiyesine yönelik yapmış olduğu harcamalar olumsuz zarar kapsamına girmektedir. Böylece, olumsuz zarar talebi ile zarar gören taraf, amaçlamış olduğu borç ilişkisinin hüküm ifade edeceği veya etmeye devam edeceği yönünde karşı tarafın kendisinde yaratmış olduğu güvenin boşa çıkarılmasından kaynaklanan kayıplarının giderilmesini istemektedir ${ }^{93}$.

ANTALYA, Borçlar 3, N. 1317.

OĞUZMAN/ÖZ, N. 1268; HUGUENIN, N. 872, 1554; ERGÜNE, Olumsuz Zarar, s. 38-39.

OĞUZMAN/ÖZ, N. 1282; ERGÜNE, Olumsuz Zarar, s. 26 vd.

Bu nevi zararlar, sözleşmesel menfaatlerin değil "bütünlük menfaatlerinin” ihlalinden doğan ve olumlu ya da olumsuz zarar içerisinde değerlendirilemeyen zararlardır. Bu yönde bkz. ERGÜNNE, Olumsuz Zarar, s. 32.

ANTALYA, Borçlar 3, N. 3033; BAYGIN, s. 362.

ANTALYA, Borçlar 3, N. 3015; ERGÜNE, Olumsuz Zarar, s. 287. 
766 | Arş. Gör. Dr. Özkan ÖZYAKIŞIR / Arş. Gör. Muhammed K. GANBARİ

Olumsuz zararın kapsamı tespit edilirken zarar ile zarara sebebiyet veren olay arasındaki uygun illiyet bağının varlığı mutlaka aranır. Buna göre güvenin ihlali yüzünden meydana geldiği ispat edilebilen her zarar, olumsuz zararın içeriğine dahil olacaktır ${ }^{94}$. Bu sebepledir ki olumsuz zarar kalemini oluşturabilecek her malvarlığı kaybının teker teker sayılması mümkün değildir95. Ancak uyandırılan güvene ile arasında uygun illiyet bağı bulunan bazı zarar kalemleri "fiili zarar" ve "yoksun kalınan kâr" başlıkları altında aşağıdaki gibi incelenebilir ${ }^{96}$.

\section{a. Fiili Zarar}

Olumsuz zararın kapsamına giren ilk kalem, fiili zararlardır ${ }^{97}$. Fiili zarar, zarar verici olay nedeni ile malvarlığında oluşan rıza dışı miktar ve değer azalması olarak tanımlanabilir ${ }^{98}$. Fiili zararların bir liste olarak sunulması güçtür. Bu sebeple fiili zararlar temel olarak üç ana başlık altında toplanır. İlk olarak "amaçlanan sözleşmeyi kurmaya yönelik olarak doğrudan doğruya yapılan masraflar", olumsuz zararın içeriğinde yer alan en tipik fiili zarar kalemi olarak karşımıza çıkmaktadır ${ }^{99}$. Bunlar; sözleşme öncesi görüşmelerin kesilmesi, sözleşmenin tamamlanamaması ve hükümsüz olarak kurulan sözleşme için yapılan harcamalardır. Bu bağlamda noter harçları, pul ve posta giderleri, telefon ve seyahat masrafları, vergiler, sözleşmenin kurulmasına aracılık eden komisyoncuya, fikir danışılan hukuk danışmanına ödenen ücretler gibi giderler sözleşme öncesi görüşmelerin kesilmesinden doğan olumsuz zarar kalemlerine misal olarak gösterilebilir ${ }^{100}$. Yargıtay da olumsuz zararın kapsamına, ilk olarak sözleşmenin ifa

94 HUGUENIN, N. 1556; DEMIRCIOĞLU, s. 263; ERGÜNE, Olumsuz Zarar, s. 287; GÜVENÇ, s. 398.

95 ERGÜNE, Olumsuz Zarar, s. 288.

96 "Menfi zararın hesabında yüklenicinin işi üstlendiğ i fiyatla, yeni fiyatlar arasındaki farkın alınması doğru değildir. Menfi zarar; a) Fïli zararlar (sözleşmenin kurulması, işin görülmesi için yapılan giderler, ör: noter, posta giderleri ...) b) Yoksun kalınan kazançlardır." (T.C. YARGITAY 15. HUKUK DAİRESI E. 1991/4076 K. 1992/1584 T. 26.3.1992) (KAZANCI). Olumsuz zararlar kalemleri için ayrıca bkz. TANDOĞAN, s. 427-428; KUTLU SUNGURBEY, s. 146 vd.; YILDIRIM/BAŞPINAR, s. 1098. OĞUZMAN/ÖZ, N. 1284; HUGUENIN, N. 874.

98 EREN, N. 1634; OĞUZMAN/ÖZ, N. 1284; YILDIRIM/BAŞPINAR, s. 1096; BÜYÜKSAĞİŞ, s. 84.

99 TANDOĞAN, s. 427; ANTALYA, Borçlar 3, N. 3037.

100 ERGÜNE, Olumsuz Zarar, s. 289. 
edileceğine güvenilerek yapılan harcamaların gireceğini belirlemiştir. Böylece olumsuz zararın öncelikle fiilen yapılan harcamalar, "fiili zararlar" kaleminden meydana geldiği saptanmıştır ${ }^{101}$.

Yine "sözleşmenin kurulduğuna inanan yahut kurulacağına güvenen taraf bu sözleşmenin ifasına yönelik olarak masraflar" yapacaktır. Bu nevi masraflar da fiili zararın kapsamına girecek diğer bir kalemdir ${ }^{102}$. Doktrinde bu nevi zararlara örnek olarak sözleşme konusunun nakliyesi için yapılan masraflar, devir-tescile dair masraflar, malın sigortasına dair primler, gümrük masrafları, ifa için bankadan temin edilen kredilere ilişkin faiz ödemeleri, bir eser sözleşmesi için araziyi düzeltme ve şantiye kurma masrafları, mimari proje çizdirme masrafları gibi giderler gösterilmektedir ${ }^{103}$.

Son olarak "kurulan yahut kurulduğu düşünülen sözleşme sebebiyle yerine getirilen edim yahut bu sözleşmeye dayah giderler" de olumsuz zarar içerisindeki fiili zarar kalemini oluşturur. Bir sözleşmenin kurulduğuna inanan kimsenin yerine getirdiği edim malvarlığından çıkmış bir değer olması sebebiyle elbette olumsuz zarar içerisinde yer alır ${ }^{104}$. Yine sözleşmeye dayalı olarak üçüncü kişilere karşı ortaya çıkan sorumluluklar, söz gelimi ceza koşulu ödemeleri105 ile oluşan fiili ilişkinin tasfiyesine dair her nevi gider de fiili zarar olarak nitelendirilebilecektir ${ }^{106}$.

\section{b. Yoksun Kalınan Kâr}

Olumsuz zararı oluşturan diğer bir kalem ise yoksun kalınan kârdır. Hüküm ifade edeceğine ${ }^{107}$ veya kurulacağına güvenilen sözleşme

101 T.C. YARGITAY 15. HUKUK DAİRESİ E. 2003/1716 K. 2003/4880 T. 20.10.2003 (KAZANCI); T.C. YARGITAY 15. HUKUK DAİRESİ E. 2003/5347 K. 2004/2196 T. 19.4.2004 (KAZANCI).

TANDOĞAN, s. 428; ANTALYA, Borçlar 3, N. 3037; ERGÜNE, Olumsuz Zarar, s. 291.

ERGÜNE, Olumsuz Zarar, s. 291.

104 ANTALYA, Borçlar 3, N. 3037.

105 Ceza koşulu ödemelerinin culpa in contrahendo sorumluluğu bağlamında olumsuz zarar kapsamında olduğu yönünde bkz. BGE 140 III 200.

106 ANTALYA, Borçlar 3, N. 3037.

107 “Davacı, taahhüdünü yerine getirmeyerek sözleşmenin feshine neden olan davahdan bu yüzden uğradiğı olumsuz zararının ödetilmesini isteme hakkına sahiptir. Ancak zararın ne şekilde belirlenmesi gerektiği önem kazanmaktadır. Burada olumsuz zararı miktarı 
yüzünden, zarar gören kişi aynı şartlarla ya da daha elverişli koşullarla başka bir sözleşme yapma fırsatını kaçırılmış ve bu sebeple kârdan mahrum kalmış ise uğranılan bu kayıp yoksun kalınan kâr olarak ifade edilir ${ }^{108}$. Culpa in contrahendo sorumluluğu noktasında, kaçırılan sözleşme fırsatları da yoksun kalınan kâr kalemi olarak olumsuz zarar içerisinde, zarar verenden talep edilebilir ${ }^{109}$.

Yoksun kalınan kâr ile duyulan güven arasında bir illiyet bağının bulunması gerektiği, açıtır ${ }^{110}$. Bu noktada illiyet bağı sözleşmenin kurulacağına veya geçerli kurulduğuna dair kişinin duyduğu güvenle ilişkilendirilir. Şöyle ki eğer taraflar arasında sözleşme görüşmeleri yapılmasaydı, güvenen kişi aynı veya daha elverişli teklifleri kaçırmayacaktı. Bu sebeple, kaçırılan diğer sözleşme fırsatlarının getireceği muhtemel kazanç bir başka ifadeyle yoksun kalınan kâr, güvenin boşa çıkmasının sonucu olup, zarar ve fiil arasında uygun illiyet bağı bulunmaktadır ${ }^{111}$.

belirlenirken, kural olarak kaçırılan firsat ilkesi çerçevesinde, her bir davalı açısından kendisinden sonraki en iyi ikinci fiyat teklifiyle, makul sürede yöntemince yapılmış sonraki ihalede gerçekleşen fiyat arasındaki farkın değerlendirilmesi gerekir. Öğreti ve uygulamada menfi zarar, "uyulacağına ve yerine getirileceğine inanılan bir sözleşmenin hüküm ifade etmemesi ve yerine getirilmemesi yüzünden güvenin boşa çıkması nedeniyle uğranılan zarar" olarak kabul edilmektedir. Sözleşmenin ifa edileceğine inanılarak başka bir sözleşme yapma firsatının kaçırılması nedeniyle uğranılan zarar da menfi zarar kapsamında değerlendirilmektedir. Davacının menfi zararının saptanmasında, davalı açısından, davalının teklifinden sonraki en iyi teklif ile sonraki ihale fiyatı arasındaki fark esas alınmalıdır. Değinilen bu hususlar doğrultusunda belirlenen bedel davacının olumsuz zararın gösterir." (T.C. YARGITAY 3. HUKUK DAİRESİ E. 2017/6160 K. 2019/2789 T. 1.4.2019) (KAZANCI).

OĞUZMAN/ÖZ, N. 1285; ANTALYA, Borçlar 3, N. 3043; HUGUENIN, N. 874; ERGÜNE, Olumsuz Zarar, s. 301; GONZENBACH, s. 213; “Davacı, sözleşme konusu malı davalıdan almayıp da başka bir kişiden alma olană̆ı varsa (kaçırılan firsat), o kişiye yapılacă̆ı varsayılan ödeme ile sözleşmenin hükümsüzlü̈̆̈̈ nedeniyle ayn malı almak için ödemek zorunda kaldığı tutar arasındaki farkı, yani menfi zararın ister." (T.C. YARGITAY HUKUK GENEL KURULU E. 1989/13-392 K. 1990/1 T. 17.1.1990) (KAZANCI).

"Sözleşmenin geçerliliğine ifa edileceğine inanılarak başka bir sözleşme yapma fırsatının kaçırılması nedeniyle uğranılan zarar da olumsuz zarar kapsamında değerlendirilmektedir." (T.C. YARGITAY 13. HUKUK DAİRESİ E. 1995/1133 K. 1995/1891 T. 27.2.1995) (KAZANCI). 


\section{Culpa In Contrahendo Sorumluluğunda Zarar Görenin}

\section{Kusuru}

Edim yükümlülüğünden kaynaklanmamasına rağmen culpa in contrahendo sorumluluğunda da tarafların "birlikte kusurundan" bahsetmek mümkündür. Gerçekten de bir sözleşmeye ait müzakerelerin tarafların karşılıklı kusurları ile sona ermesi imkân dahilindedir. Bu halde bir tarafın kusurunun var olması onun tazminat talebinde bulunmasına ilke olarak engel değildir. Nitekim doktrinde zarar görenin kusuru, tazminattan indirim sebebi olarak görülmektedir ${ }^{112}$. Ancak eğer zarar görenin kusuru zararın oluşması açısından, zarar verenin eylemi ile zarar arasındaki illiyet bağını kesecek yoğunluktaysa, zarar veren tazminat yükümlülüğünden kurtulmaktadır ${ }^{113}$. Yine birlikte kusur halinde tarafların kusurları eşit ise baskın görüşe göre ilke olarak bu, tazminat sorumluluğunu ortadan kaldırmaz ${ }^{114}$. Kanaatimizce birlikte kusurda, culpa in contrahendo sorumluluğu açısından bu genel esaslardan farklı düşünülmesini gerektiren bir hal söz konusu değildir. Ne var ki İsviçre Federal Mahkemesi birlikte kusur halinde, tarafların kusurlarının denk olması noktasında farklı düşünmektedir. Yüksek Mahkeme'ye göre culpa in contrahendo sorumluluğu bakımından taraflarının kusurların denk olması durumunda tazminat sorumluluğu doğmaz ${ }^{115}$.

\section{SONUÇ}

1. Modern hukuk, borç ilişkisi kavramını gelişen ihtiyaçlar çerçevesinde ele alarak değerlendirmiş, borç ilişkisinin edim yükümlülükleri ve koruma yükümlülüklerinden oluştuğu sonucuna varmıştır. Edim yükümlülüğü, tamamen sözleşmenin somut içeriği ile alakalıdır ve esas olarak tarafların karşılıklı iradelerinden doğmaktadır. Bu yönü ile kurulmamış ya da geçersiz hale gelmiş bir sözleşmeden herhangi bir edim yükümlülügü doğmayacaktır. Koruma yükümlülükleri ise taraf iradelerinden bağımsız doğarlar. İşlem temasına girişen taraflar arasında oluşan güven

\footnotetext{
112 TANDOĞAN, s. 318; EREN, N. 2397.

113 TANDOĞAN, s. 318; EREN, N. 2396.

114 BAYSAL, Başak, Zarar Görenin Kusuru, İstanbul 2012, s. 137.

115 BAYSAL, s. 137; BGE 106 II 36.
} 
ilişkisi, taraflara, koruma yükümlülükleri yükler. Bu yükümlülükler, işlem temasının gerçekleşmesi ile kendiliğinden ve kanun gereği doğarlar.

2. İşlem teması, basit sosyal bir temasın ötesinde anlam ifade etmektedir. Burada, tarafların hukuki değer ve menfaatlerini birbirlerinin etkisine ve özellikle diğer tarafın hâkim olduğu bir alana açması sonucunu doğuran özel hukuki bir temas söz konusudur. Güven ilişkisini gerçekleştiren özel hukuki temas, sözleşme öncesinde, sözleşmenin ifası aşamasında ve sözleşmenin ifasından sonra mevcut olabilir.

Sözleşme öncesi görüşmeler, sözleşme ilişkisi içine girmek isteyen taraflar açısından ilk özel hukuki temastır. Bu ilk temas, taraflara koruma yükümlülükleri yüklemektedir. İşte culpa in contrahendo, taraflar arasında geçerli bir sözleşme kurulmadan önce ilk özel hukuki temas ile başlayan koruma yükümlülüklerinin ihlalinden doğan sorumluk halini ifade etmektedir.

3. Sözleşme öncesi görüşmelerin taraflardan birinin objektif haklı bir nedene dayanmayan davranışı sonucu kesilmiş ve sözleşme yapılacağına dair uyandırılan güvenin bu şekilde boşa çıkarılmış olduğu durumlarda da oluşan zarar, culpa in contrahendo sorumluluğu çerçevesinde tazmin edilmelidir.

4. Sözleşme öncesi görüşmelerin kesilmesi nedeni ile uğranılan zarar, taraflardan birinin amaçlanan sözleşme ile hukuken bağlanacağına inanması ve bu inanışın boşa çıkması sebebi ile gördüğü zarardır. Bu zarar, olumsuz zarar olarak nitelendirilmektedir. Zira olumsuz zarar, sözleşmenin kurulması, geçerliliği veya ifasına ilişkin karşı tarafta uyandırılan güvenin boşa çıkarılması sebebiyle oluşan zarardır.

5. İlk işlem temasından itibaren karşı tarafta uyandırılan güvenin ihlali ile illiyet bağ 1 içerisinde bulunun her zarar kalemi olumuz zarar kapsamında değerlendirilir. Bu sebeple her bir zarar kaleminin sayılması mümkün olamayacağından, bunlar fiili zarar ve yoksun kalınan kâr başlıkları altında toplanmıştır. 


\section{KAYNAKLAR}

AKÇAAL, Mehmet, Sözleşme Sonrası Sorumluluk, 1. Baskı, Mayıs 2018.

ANTALYA, Gökhan, Borçlar Hukuku Genel Hükümler Cilt: V/1, 1, Genişletilmiş 2. Baskı, Ankara 2019. (Borçlar 1)

ANTALYA, Gökhan, Borçlar Hukuku Genel Hükümler Cilt: V/1, 3, Genişletilmiş 2. Baskı, Ankara 2019. (Borçlar 3)

AYVERDİ, İlhan, Misalli Büyük Türkçe Sözlük, İstanbul 2010.

BAYGIN, Cem, "Culpa in Contrahendo Sorumluluğu ve Amerikan Hukukundaki Uygulaması", AÜEHFD, C. IV, S. 1-2 (2000), s. 345377.

BAYSAL, Başak, Zarar Görenin Kusuru, İstanbul 2012.

BROX, Hans ve WALKER, Wolf-Dietrich, Allgemeines Schulrecht, Grundrisse des Recht, 34. Auflage, München 2010.

BÜYÜKSAĞİş, Erdem, Yeni Sosyo-Ekonomik Boyutuyla Maddi Zarar Kavramı, İstanbul 2007.

DEMIRCIOĞLU, Huriye Reyhan, Güven Esası Uyarınca Sözleşme Görüşmelerindeki Kusurlu Davranıştan Doğan Sorumluluk (Culpa in Contrahendo Sorumluluğu), Ankara 2009.

EREN, Fikret, Borçlar Hukuku Genel Hükümler, 24. Baskı, Ankara 2019.

ERGÜNE, Mehmet Serkan, "Culpa in Contrahendo Sorumluluğunda Olumlu Zararın Tazmini", Prof. Dr. Rona Serozan'a Armağan, C. I, İstanbul 2010, s. 909-926. (Culpa in Contrahendo)

ERGÜNE, Mehmet Serkan, Olumsuz Zarar, İstanbul 2008. (Olumsuz Zarar)

ERNST- KOLBL, Michael, Schuldrecht Allgemeiner Teil, Niederle Media 2008.

FROST, Marina, Vorvertragliche und Vertragliche Schutzpflichten, Schriften zum Bürgerlichen Recht, Band 63, Ducker und Humolt/ Berlin 1981.

GONZENBACH, Rainer, Culpa in Contrahendo im schweizerischen Vertaragsrecht, Bern 1987. 
774 | Arş. Gör. Dr. Özkan ÖZYAKIŞIR / Arş. Gör. Muhammed K. GANBARİ

GÜVENÇ, Özgür, "Culpa in Contrahendo Sorumluluğu Bağlaminda Sözleşme Görüşmelerinin Kesilmesi", Gazi Üniversitesi Hukuk Fakültesi Dergisi C. XVIII, Y. 2014, S. 3-4, s.363-405.

HEHLI, Christoph, Die Alternativen Rechtsbehelfe des Käufers unter besonderer Berücksichtigung der Haftung aus Culpa in Contrahendo, Band 33, Zürich 2008.

HUGUENIN, Claire, Obligationenrecht- Allgemeiner und Besonderer Teil, Zürich 2012.

KALKAN OĞUZTÜRK, Burcu, Güven Sorumluluğu, İstanbul 2008.

KARABAĞ BULUT, Nil, Üçüncü Kişiyi Koruyucu Etkili Sözleşme, İstanbul 2009.

KAŞAK, Fahri Erdem, Sözleşme Özgürlüğünün Sınırı Olarak Kanunun Emredici Hükümlerine Aykırılık, İstanbul 2019.

KIRCA, Çiğdem, Bilgi Vermeden Dolayı Üçüncü Kişiye Karşı Sorumluluk, Ankara 2004.

KUTLU SUNGURBEY, Ayfer, Yetkisiz temsil Özellikle Culpa in Contrahendo - Sözleşme Görüşmesinde Kusur ve Olumsuz Zarar, İstanbul 1988.

LANGE, Hermann, Handbuch des Schuldrecht, Schadensersatz, 2. Auflage, Tübingen, 1990.

MEDICUS, Dieter, Allgemeiner Teil des BGB, Heidelberg 1982.

OĞUZMAN, M. Kemal/ÖZ, M. Turgut, Borçlar Hukuku Genel Hükümler Cilt I, Yeni Türk Borçlar Kanunu'na Göre Güncellenip, Genişletilmiş 16. Bası, İstanbul 2018.

POHLMANN, Andre, Die Haftung wegen Verletzung von Aufklärungspflicht, Schriften zum Bürgerlichen Recht, Band 268, Dunker und Humbolt/ Berlin 2002.

REHM, Gebhard M., Aufkärungspflichten im Vertragsrecht, Münchener Universitätsschriften Reihe der Juristischen Fakultät, Band 179, München 2003.

SEROZAN, Rona, "Sözleşmenin müspet ihlali ve culpa in contrahendo", İstanbul Üniversitesi MHAD, No. 18, İstanbul 1990, s. 27-42. TANDOĞAN, Haluk, Türk Mesuliyet Hukuku, Ankara 1961. 
Sözleşme Öncesi Görüşmelerin Kesilmesi Bağlamında Culpa In Contrahendo| 775

YILDIRIM, Fadıl/BAŞPINAR, Veysel, “Doktrin ve Uygulama Açısından Türk-İsviçre Hukukunda Doğrudan Doğruya ve Dolaylı Zarar Ayrımı", Prof. Dr. Bilge Öztan'a Armağan, Ankara 2008, s.10931125. 